\title{
Study of prevalence of gestational syphilis in a maternity hospital of the SUS network
}

Sexually transmitted infections (STIS) cause serious public health problems, among STIs, which can be affected, as it is a sexually transmitted infectious disease caused by the bacterium Treponema pallidum. Thus, the objective of the research was to conduct a study of the prevalence of pregnant women in a maternity hospital of the SUS network in the city of Juazeiro do Norte-CE, from January 2014 to June 2017. This study showed a total of 184 women reported where the highest prevalence of gestational cases was in the period of 2015 with 59 (32\%) cases, visas or the highest number of notifications in December, followed by 2016 with $46(25 \%)$ cases, but they must be taken into account in the year from 2017, there are cases registered until June. It was also possible to observe a number of $37(20.1 \%)$ cases of teenage pregnancy disturbed by syphilis, where it ended up being one of the most worrying occurrences, not so related to sexuality and causing diseases, causing a social problem, more also in the clinical situation of risk or factors that impact your health. Through this study, we pointed out a reflection on the problem of the number of adult women with the same number of $81 \%$ of prenatal achievements, and despite its restrictions, this work was also able to show in general terms, the epidemiological paths followed by the disease in the period from 2014 to 2017, subsidizing the development of future research in this field of knowledge, to raise the main facts that may justify part of the number of reported cases.

Keywords: Syphilis; Gestation; Prenatal; Maternity; Obstetrics.

\section{Estudo da prevalência de sífilis gestacional em uma maternidade da rede SUS}

\begin{abstract}
As infecções sexualmente transmissiveis (IST) causam sérios problemas de saúde pública, entre as IST, que podem ser afetadas, por se tratar de uma doença infecciosa sexualmente transmissível causada pela bactéria Treponema pallidum. Assim, o objetivo da pesquisa foi realizar um estudo de prevalência de gestantes em uma maternidade da rede SUS do município de Juazeiro do Norte-CE, no período de janeiro de 2014 a junho de 2017 . Este estudo apresentou um total de 184 mulheres relataram onde a maior prevalência de casos gestacionais foi no período de $2015 \mathrm{com} 59$ (32\%) casos, vistos ou maior número de notificações em dezembro, seguido por 2016 com 46 (25\%) casos, mas devem ser considerados conta no ano de 2017, há casos registrados até junho. Também foi possível observar um número de $37(20,1 \%)$ casos de gravidez na adolescência perturbada por sífilis, onde acabou sendo uma das ocorrências mais preocupantes, não tão relacionada à sexualidade e causando doenças, causando um problema social, mais também na situação clínica de risco ou fatores que impactam sua saúde. Por meio deste estudo, apontamos uma reflexão sobre a problemática do número de mulheres adultas com igual número de $81 \%$ de realizações no pré-natal e, apesar de suas restrições, este trabalho também foi capaz de evidenciar, de forma geral, os caminhos epidemiológicos percorridos pelo a doença no período de 2014 a 2017, subsidiando o desenvolvimento de pesquisas futuras nesta área do conhecimento, para levantar os principais fatos que podem justificar parte do número de casos notificados.
\end{abstract}

Palavras-chave: Sífilis; Gestação; Pré-natal; Maternidade; Obstetrícia.

Topic: Epidemiologia

Reviewed anonymously in the process of blind peer.

José Geraldo de Alencar Santos Júnior (iD Centro Universitário Vale do Salgado, Brasi http://lattes.cnpq.br/3128932820045618 http://orcid.org/0000-0002-6214-7660

geraldoalencar@univs.edu.br

João Pedro Viana Rodrigues (iD

Universidade Federal do Ceará, Brasil

http://lattes.cnpq.br/7518760141485649

http://orcid.org/0000-0002-0549-6215

ipedroviana@alu.ufc.br

Amparo Carmen Rosália Narvaez Vargas

Faculdade de Medicina Estácio Juazeiro do Norte, Brasil

junior_alencar_@hotmail.com

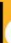

DOI: $10.6008 / C B P C 2236-9600.2020 .003 .0008$
Received: 10/06/2020

Approved: 19/08/2020

Antoniel dos Santos Gomes Filho (iD)

Centro Universitário Vale do Salgado, Brasil

http://lattes.cnpq.br/9563145614494252

http://orcid.org/0000-0003-2230-4315

antoniel.historiacomparada@gmail.com
Referencing this:

SANTOS JÚNIOR, J. G. A.; RODRIGUES, J. P. V.; VARGAS, A. C. R. N. GOMES FILHO, A. S.. Study of prevalence of gestational syphilis in a maternity hospital of the SUS network. Scire Salutis, v.10, n.3, p.6772, 2020. DOI: http://doi.org/10.6008/CBPC2236-9600.2020.003.0008 


\section{INTRODUCTION}

Sexually transmitted infections (STIS) cause serious public health problems, among STIs, which can be affected, as it is a sexually transmitted infectious disease caused by the bacterium Treponema pallidum. It has vertical transmission, from women by right, during a pregnancy that causes great damage and health, social and economic damages. It can also result in miscarriages, fetal changes, neonatal deaths, asymptomatic or symptomatic neonates, which can progress to serious complications if not applied (ARAÚJO et al., 2016). The quality of management and participation assistance is an important determining factor in reducing incidence rates and incidence of vertical transmission, and the main control of the disease is based on serological screening and the appropriate treatment of the manager and his partner (SILVA et al., 2015).

Aware of the perinatal risks and the magnitude of the gestures of the Ministry of Health (MS), included in 2005 the list of diseases in the national list of compulsory notification diseases, according to port number 33, of July 14, 2005.5 (BRASIL, 2007). The diagnosis of syphilis during pregnancy is carried out in cases where the manager presents samples of clinical diseases and/or treponemic non-reactive serology, with any titration, which is not prenatal, emergency hospitalization or delivery, being the main epidemiological objective or monitoring the infection in pregnant women, which does not concern treatment, prevention and control (SOARES et al., 2014).

However, the treatment recommended by the WHO is a benzathine penicillin capable of preventing $97 \%$ of vertical transmission cases, with the best results when treatment is carried out around the 24th to 28th gestational week. This same treatment with benzathine penicillin is applied to partners, allowing greater treatment coverage (WHO, 2014).

It is seen that a pregnancy is characterized by clinical and outpatient manifestations, resulting in complications of the vast majority of neonates. Thus, the objective of the research was to carry out a study of the prevalence of pregnant women in a SUS maternity hospital in the city of Juazeiro do Norte-CE, from January 2014 to June 2017, with a performance improvement in the quality of care with it, decreasing the high-risk pregnancy rates and neonatal complications. It is hoped that the data of this research include study data for academics and health professionals, without an early diagnosis of pregnant patients, with this we intend to reduce the number of prevalent cases.

\section{METHODOLOGY}

\section{Type of study}

This is a descriptive study with data from the mandatory notification forms of the Notification Recording Information System (SINAN), which consist of a standardized form with sociodemographic and clinical information performed by health professionals. According to Gil (2002), as descriptive research has as its primary objective a description of the characteristics of the population or phenomenon or else the establishment of a relationship between variables. 


\section{Study location}

The study was carried out at Hospital Maternidade São Lucas - HMSL, which is part of the SUS network, located in the municipality of Juazeiro do Norte, Ceará, Brazil. The city of Juazeiro do Norte is located in the south of the State of Ceará, in the Cariri region, has only one maternity hospital serving the population of low socioeconomic level, and according to data from the Brazilian Institute of Geography and Statistics (IBGE, 2017), and has a population of 270,383 inhabitants. It is located $533 \mathrm{~km}$ from Fortaleza, bordering the cities of Crato, Barbalha, Caririaçu and Missão Velha in the Cariri valley region. It has a tropical climate and its area is $248,832 \mathrm{~km}^{2}$.

\section{Data collect}

Data collection was carried out in October 2017, from the reading of the SINAN files, found at the time of the survey, shortly after being authorized by the faithful depositary.

\section{Inclusion and exclusion criteria}

All cases of gestational syphilis registered with SINAN in the years 2014 to 2017 were included, which met the criterion for defining a confirmed case according to the Ministry of Health (BRASIL, 2005). Duplicate cases, identified from the analysis of the SINAN notification forms, were excluded.

\section{Data analysis}

For a better understanding of the prevalence, variables were studied according to the information in the syphilis notification form in pregnant women, which consist of: prevalence of cases per year, frequency of cases by age, prenatal care, partner treatment, location primary maternal diagnosis. The data were presented in the form of tables and graphs prepared using the Excel software Microsoft Office 2010.

\section{Ethical aspects}

The research project was approved by the Ethics Committee of the Medicine Faculty Estácio Juazeiro do Norte - FMJ under Opinion No. 2.696.856 and was carried out in accordance with the Resolution of the National Health Council (CNS) No. 466, of December 12 ${ }^{\text {th }}, 2012$.

\section{RESULTS AND DISCUSSION}

This study showed a total of 184 women notified where the highest prevalence of gestational syphilis was in the period of 2015 with 59 (32\%) cases, considering the highest number of reports in December, followed by 2016 with 46 (25\%) cases, however the year 2017 should be taken into account, as the registered cases were until June (Chart 1 ).

However, there are limitations inherent to the method used and the collection of secondary data from official sources, and it is not possible to measure possible under-registration, underreporting, 
classification errors and incomplete filling of notification forms. The own notification forms, filled out for all pregnant women who had clinical characteristics and reactive non-treponemic serology during the maternity care corresponds to 136 (73.9\%) cases, and another 48 (26.1\%) were still diagnosed in the Basic Unit of Health, with reagent non-treponemic serology being repeated in the maternity hospital during care.

Frame 1: Monthly distribution of the frequency of syphilis cases. Juazeiro do Norte (CE), Brazil (2014-2017).

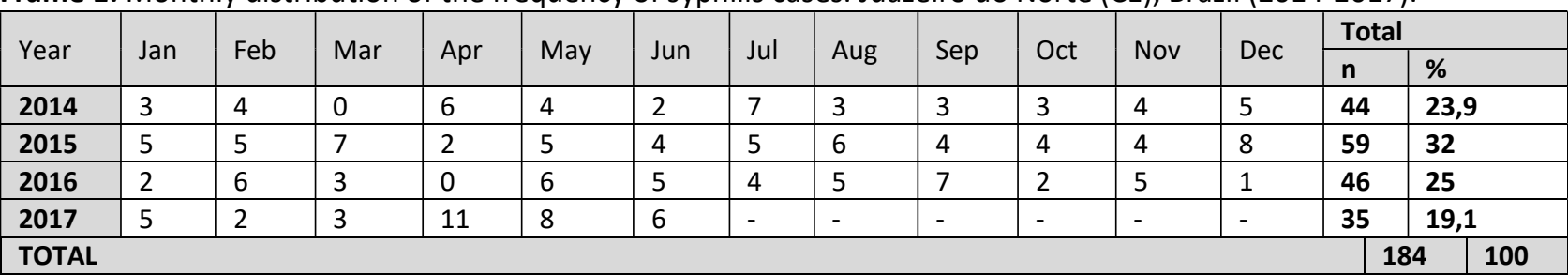

A large number was observed in the prevalence of pregnant women with syphilis during all periods. This increase has also been reported in other cities and states in Brazil (BOWEN et al., 2015). Women with syphilis are mainly young adults aged 20 to 30 years old $(60.8 \% n=112)$ (Table 1$)$ and who have had prenatal care (81\% n 149) (Graph 1), similar profile to that presented by other studies (CAMPOS et al., 2010).

Table 1: Characterization of the reported cases of gestational syphilis according to the age and educational level of the pregnant woman. Juazeiro do Norte (CE), Brazil (2014-2017).

\begin{tabular}{|c|c|c|c|c|c|c|}
\hline \multirow{2}{*}{ Faixa etária } & \multirow{2}{*}{2014} & \multirow{2}{*}{2015} & \multirow{2}{*}{2016} & \multirow{2}{*}{2017} & \multicolumn{2}{|c|}{ Total } \\
\hline & & & & & $\bar{n}$ & $\%$ \\
\hline Até 19 anos & 11 & 9 & 10 & 7 & 37 & 20,1 \\
\hline $20-30$ anos & 25 & 40 & 26 & 21 & 112 & 60,8 \\
\hline$>30$ anos & 8 & 10 & 10 & 7 & 35 & 19,1 \\
\hline
\end{tabular}

It was also possible to observe a number of $37(20.1 \%)$ cases of pregnancy in adolescence disturbed by syphilis, where it ends up being one of the most worrying occurrences, not only related to sexuality and which causes consequences, becoming a social problem, but also because of the clinical situation of the risk of boarding or factors that impact your health. So, we emphasize how important it is to create strategies to reduce the number of these cases and, for that, it is necessary to insist on sex education actions for the prevention of a teenage pregnancy. Where it is advised that health, education and family members with whom the adolescent lives have a careful attention (CERTO et al., 2014).

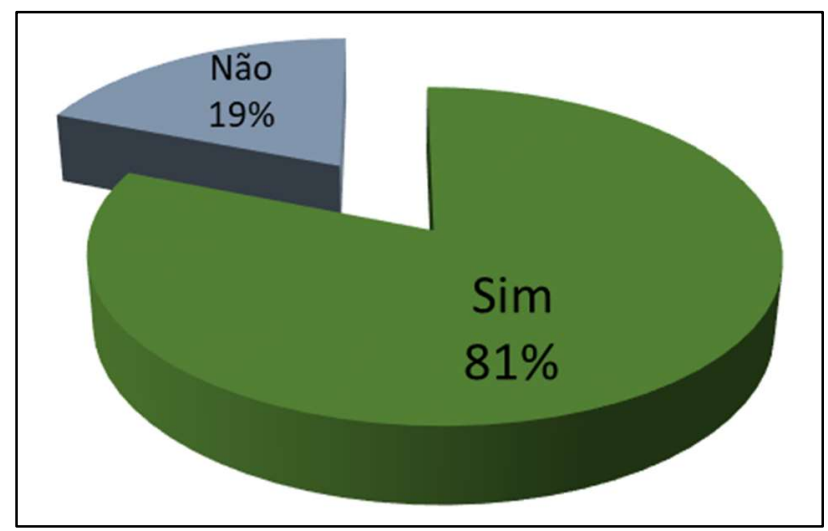

Graph 1: Percentage of 184 (100\%) women notified who underwent prenatal care. Juazeiro do Norte (CE), Brazil (2014-2017).

Prenatal care is of great importance for maternal and child health. During this period, activities 
related to the identification of risks for the pregnant woman and the baby must be developed, allowing the prevention of numerous complications, in addition to reducing or eliminating risk factors and behaviors associated with various health problems, including syphilis. It is recommended by the Ministry of Health that prenatal care should have at least six consultations with health professionals, with at least two of them carried out by a doctor. It is also recommending that the service starts in the first gestational trimester (DOMINGUES et al., 2015).

In Brazil, the proportion of women with prenatal care is greater than $95 \%$, but women without any prenatal consultation are those with the highest prevalence of syphilis during pregnancy and the greatest social vulnerability (DOMINGUES et al., 2013).

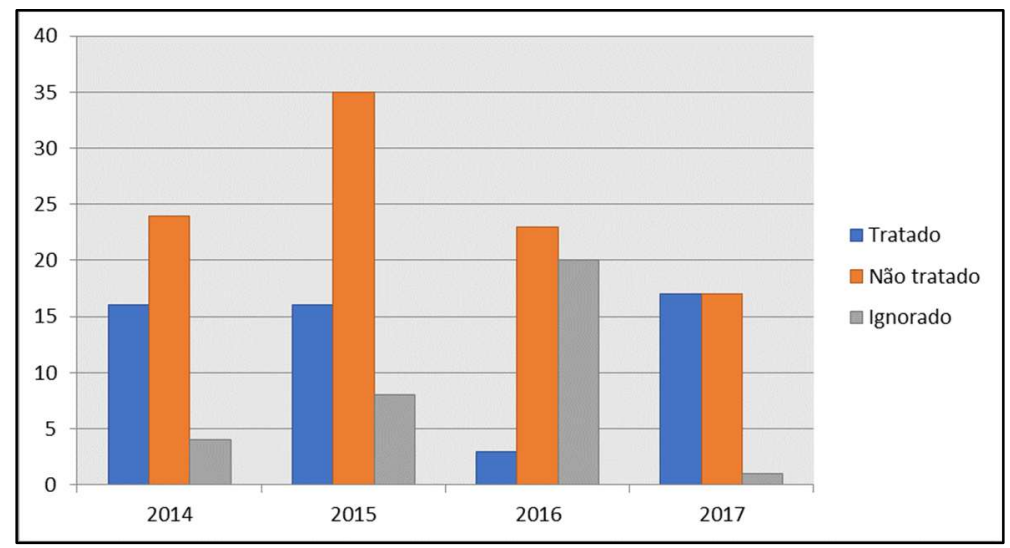

Graph 2: Characterization of notified cases of gestational syphilis according to the partner's treatment.

According to what is shown in Graph 2, there was no adequate treatment of sexual partners in $53.8 \%$ of cases ( $n=99$ ) from 2014 to 2017. In 2016, there were 20 ignored cases, as it was seen in the notification that they even did the treatment at the Basic Health Unit. The main reasons identified for which treatment was not carried out correspond to the fact that the partner has no longer had contact with the pregnant woman, or the partner has not been summoned for treatment, and only one case where the partner was summoned and did not attend, and among other reasons.

Partner treatment is important to prevent reinfection during pregnancy, as well as an opportunity to treat and prevent new cases of sexually transmitted infections in the general population. Therefore, it is seen in the literature that authors point out the priority actions for notification of syphilis, the active search, the appropriate treatment of sexual partners and the serological monitoring that proves the cure of the disease, these must be performed in the Basic Health Unit (FIGUEIREDO et al., 2015).

Thus, considering the importance of the records related to the monitoring of pregnant women in the SINAN forms, it is worth emphasizing the need to improve the information recorded in the medical records and cards of pregnant women, both in hospital care and in the Basic Health Unit, so that it can be done the treatment properly, thus avoiding congenital syphilis and favoring comprehensive care.

\section{CONCLUSIONS}

Through this study we point out a reflection on the problem of the number of adult women with 
syphilis even though they have $81 \%$ of prenatal achievements, and despite its limitations, this work was also able to show in general terms, the epidemiological paths taken by the disease in the period from 2014 to 2017, subsidizing the development of future research in this field of knowledge, to identify the main facts that may partially justify the number of reported cases.

Based on these considerations, it is hoped that this work can contribute to a differentiated role of medicine in the face of the problem of syphilis in pregnancy and rethink effective practices to overcome this major public health problem, working on the effectiveness of early diagnosis, treatments, and notification for a possible epidemiological study, as guaranteed by Ordinance No. 33, of July 14, 2005 (BRASIL, 2005).

\section{REFERENCES}

ARAÚJO, L. R. L.; SILVA, V. C. C.; GOUVEIA FILHO, P. S.; SOUSA, M. N. A.. Prevalência de sífilis gestacional e congênita no estado de Goiás, Brasil. Revista Ciência \& Desenvolvimento, v.9, n.2, 2016.

BOWEN, V. S. J.; TORRONE, E.; KIDD, S.; WEINSTOCK, H.. Increase in incidence of congenital syphilis: United States of America, 2012-2014. MMWR Morb Mortal Wkly, v.64, n.44, p.1241-5, 2015.

BRASIL. Ministério da Saúde. Portaria n. 33, de 15 de julho de 2005. Inclui doenças à relação de notificação compulsória, define agravos de notificação imediata e a relação dos resultados laboratoriais que devem ser notificados pelos Laboratórios de Referência Nacional ou Regional. Brasília: Ministério da Saúde, 2005.

BRASIL. Ministério da Saúde. Secretaria de Vigilância em Saúde. Diretrizes para controle da sífilis congênita. Programa Nacional de DST e Aids. Brasília: Ministério da Saúde, 2005.

BRASIL. Ministério da Saúde. Secretaria de Vigilância em Saúde. Protocolo para a prevenção de transmissão vertical de HIV e sífilis: manual de bolso. Programa Nacional de DST e Aids. Brasília: Ministério da Saúde, 2007.

CERTO, A. C. T.; GALVÃO, A.; GOMES, M. J.. Gravidez na adolescência. Viana do Castelo: Escola Superior de Saúde Instituto Politécnico de Viana do Castelo, 2014.

DOMINGUES, R. M. S. M.; VIELLAS, E. F.; DIAS, M. A. B.; TORRES, J. A.; THEME FILHA M. M.; GAMA S. G. N.; LEAL, M. C.. Adequação da assistência pré-natal segundo as características maternas no Brasil. Rev. Panam Salud Pública, v.37, n.3, p.140-147, 2015.
DOMINGUES, R. M. S. M.; SARACEN, V.; HARTZ, Z. M. A.; LEAL, M. C.. Sífilis congênita: evento sentinela da qualidade da assistência pré-natal. Revista de Saúde Pública, v.47, n.1, p.147-157, 2013.

FIGUEIREDO, M. S. N.; CAVALCANTE, E. G. R.; OLIVEIRA, C. J.; MONTEIRO, M. F. V.; QUIRINO, G. S.; OLIVEIRA, D. R..

Percepção de enfermeiros sobre a adesão ao tratamento dos parceiros de gestantes com sífilis. Northeast Network Nursing Journal, v.16, n.3, 2015.

GIL, A. C.. Como elaborar projetos de pesquisa. São Paulo: Atlas, 2002.

IBGE. Instituto Brasileiro de Geografia e Estatística. Infográficos: dados gerais do município. Rio de Janeiro: 2017.

SILVA, M. A. M.; SOUSA, J. C.; ALBUQUERQUE, S.; MOREIRA C. A.; MARTINS, M. C.. Sentimentos de gestantes com diagnóstico de sífilis. Rev. Enferm. UFPI, v.4, n.2, p.84-91, 2015.

SOARES, M. D. R. M.; SZWARCWALD, C. L.; SOUZA JUNIOR, P. R. B.; LEAL, M. C.. Prevalência de sífilis na gestação e testagem pré-natal: Estudo Nascer no Brasil. Revista de Saúde Pública, v.48, n.5, 2014. DOI: https://doi.org/10.1590/S0034-8910.2014048005114

WHO. World Health Organization. Global guidance on criteria and processes for validation: elimination of motherto-child tranmission (EMTCT) of HIV and syphilis. Geneva: World Health Organization, 2014.

A CBPC - Companhia Brasileira de Produção Científica (CNPJ: 11.221.422/0001-03) detém os direitos materiais desta publicação. Os direitos referem-se à publicação do trabalho em qualquer parte do mundo, incluindo os direitos às renovações, expansões e disseminações da contribuição, bem como outros direitos subsidiários. Todos os trabalhos publicados eletronicamente poderão posteriormente ser publicados em coletâneas impressas sob coordenação da Sustenere Publishing, da Companhia Brasileira de Produção Científica e seus parceiros autorizados. Os (as) autores (as) preservam os direitos autorais, mas não têm permissão para a publicação da contribuição em outro meio, impresso ou digital, em português ou em tradução. 